\title{
PHYSICOCHEMICAL PROPERTIES OF GROUNDWATER IN PARTS OF IRUN AKOKO, ONDO STATE, NIGERIA
}

\author{
KEHINDE IBRAHIM ADEBAYO, VICTOR ETIM NYONG, OLUWASEYE PETER OYETADE AND GODWIN AMAH
}

(Received 16 April 2021; Revision Accepted 30 June 2021)

\begin{abstract}
Ten groundwater samples from hand dug wells were collected at Irun Akoko within the basement complex of part of southwestern Nigeria. The aim of the study was to determine the groundwater suitability for both drinking and irrigation purposes. The groundwater samples were analysed for some physical and chemical constituents including $\mathrm{pH}$, Total Dissolved Solids (TDS), turbidity, $\mathrm{Na}, \mathrm{Ca}, \mathrm{Mg}, \mathrm{K}, \mathrm{Cl}, \mathrm{SO}_{4}, \mathrm{PO}_{4}$ and $\mathrm{NO}_{3}$. The $\mathrm{pH}(7.0-7.9)$ and TDS (12.26 - 19.35 $\mathrm{mg} / \mathrm{l})$ of the groundwater indicate that the water is neutral to slightly alkaline and fresh respectively. The order of relative abundance for concentration of cations in the groundwater is $\mathrm{K}>\mathrm{Ca}>\mathrm{Na}>\mathrm{Mg}$, while that of anions is $\mathrm{Cl}>\mathrm{SO}_{4}>\mathrm{NO}_{3}>\mathrm{PO}_{4}$. The concentrations of potassium in about $90 \%$ and chloride in about $40 \%$ of the samples were above the World Health Organization (WHO) standard for drinking water. Other hydro-geochemical parameters $\mathrm{Ca}$, $\mathrm{Mg}, \mathrm{Na}, \mathrm{SO}_{4}, \mathrm{PO}_{4}$ and $\mathrm{NO}_{3}$ falls within the WHO standards. Values of Sodium Absorption Ratio (SAR) classified the water as excellent for irrigation purposes. The Soluble Sodium Percentage (SSP) values classified eighty percent of the water to be of good quality and the remaining samples as fair for irrigation purposes. However, using the Magnesium Adsorption Ratio (55.0 - $68.9 \%$ ) the samples may have hazardous effects on the soil. Generally, groundwater in the study area is suitable for both domestic and irrigation uses.
\end{abstract}

KEYWORDS: groundwater, suitability, drinking water, irrigation

\section{INTRODUCTION}

Water is an elixir of life whose scarcity and contamination could have serious health implications. Potable water therefore remains a global necessity for all human beings (Haseena et al., 2017). Quantitative yield and quality of water are the crucial factor that determines its supply for domestic, agricultural and industrial uses. When the groundwater is polluted, it poses a great threat to the health of living organisms present in such environment (Alrumman et al., 2016). Eighty percent of the diseases and deaths in the developing countries are related to water contamination (UNESCO, 2007) and deterioration in water quality is responsible for about $3.1 \%$ of death occurrence globally (Pawari and Gawande (2015).
The quality of water is of great concern to experts in all countries of the world (Odukoya, 2015). In many part of the world, humans have inadequate access to potable water and most of the water sources are contaminated. In developing nations including Nigeria, there is high dependency on groundwater than surface water resources for domestic use. It is estimated that almost 60 per cent of the population living within urban areas rely on local wells for water supply (Soladoye and Ajibade, 2014). The increasing trend of over-reliance on groundwater compared to other sources seems to be partly due to lack of alternative sources and peoples' perception of groundwater as being less contaminated than other sources. The availability of cheaper well drilling technologies also contribute to the preference of groundwater over other water sources (Soladoye and Ajibade, 2014). Despite peoples' perception,

Kehinde Ibrahim Adebayo, Department of Geology, University of Calabar, Calabar, Nigeria

Victor Etim Nyong, Department of Geology, University of Calabar, Calabar, Nigeria

Oluwaseye Peter oyetade, Department of Geology, University of Calabar, Calabar, Nigeria

Godwin Amah, Department of Geology, University of Calabar, Calabar, Nigeria 
groundwater just like other water sources can equally be contaminated, the result of which will affect its usability. Haseena et al., (2017) noted that the release of domestic and industrial effluent wastes, leakage from water tanks, radioactive waste and atmospheric deposition are major causes of water pollution. As population increases, the problem of good water supply poses serious threats to human. Hence, the need to ascertain the quality of all sources of water available to households before consumption. The aim of this study is to carry out a quality assessment of the water used for both drinking and agricultural purposes in Irun Akoko area.

\section{DESCRIPTION OF STUDY AREA \\ Location, accessibility and geology}

Irun Akoko is strategically located at the hinge of Akoko North West Local Government area of Ondo State, southwestern Nigeria. It is located within latitudes $07^{0}$ 34,30 " $\mathrm{N}$ and $07^{0}, 3645^{\prime \prime} \mathrm{N}$ and within longitudes $005^{\circ}$ $38^{\prime} \mathrm{E}$ and $005^{\circ} 41^{\prime} \mathrm{E}$. It is accessible by major roads and footpaths. The major roads include roads from lkare Akoko via Ogbagi Akoko to Ado Ekiti. Other major tarred roads are those that connect the quarters (Fig. 1).

The topography of the study area ranges from 458 to $519 \mathrm{~m}$ above sea level. The study area falls under the sub-equatorial south climatic region. It has two climatic seasons, which are the wet and dry seasons. The wet season is characterized by heavy rainfall which starts in March and ends in October while the dry season starts from November to February. The dry season is characterized by the dry North Easterly Trade Wind from the Sahara Desert. The mean annual rainfall is 1500 $\mathrm{mm}$, mean annual relative humidity is above $70 \%$ and the mean annual temperature is about $27^{\circ} \mathrm{C}$ (OSMA, 2005).

The study area is underlain by four main lithologies: Granite gneiss, Charnockitic gneiss; Garnet-sillimanite gneiss and Grey gneiss. The grey gneiss is very common in the study area and covers about $45 \%$ of the study area. The granite gneiss occurs as ridges and flat exposures and light grey in colour and medium grain in texture. The garnet sillimanite gneiss and grey gneiss are more common in the lower part of Irun Akoko. Other rock types like the quartzites are also present in the study area. Structural features such as joints, faults, and folds were observed in the rocks.

Hydrogeologically, waters are found within the weathered regoliths and the fractured zone, which are considered as good aquifers (Olorunfemi and Fasuyi, 1993). The area of recharge consists of decomposed and fractured rocks which constitute secondary porosity. Shallow wells and springs are mostly prolific during the rainy season and most of them dry up completely during the dry season.

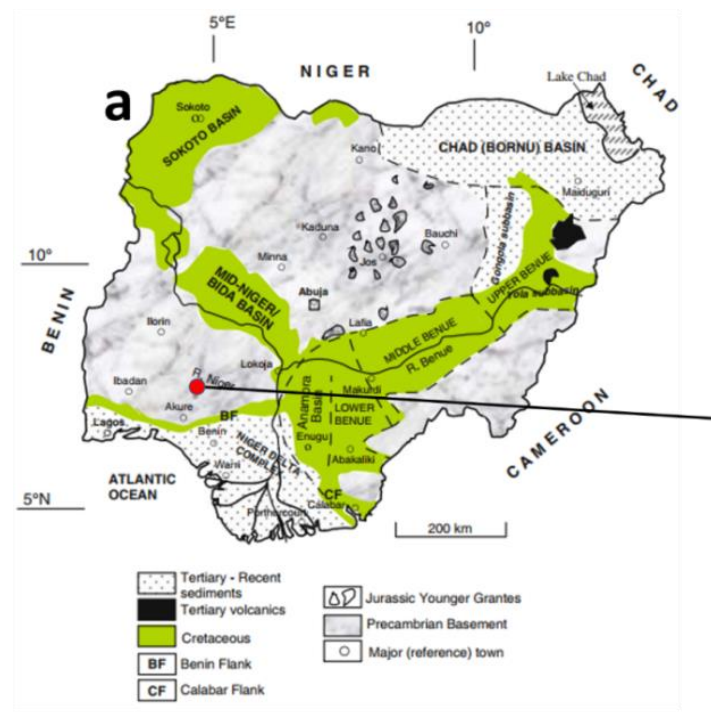

Figure 1a: geological sketch map of Nigeria (modified after Obaje, 2009)

Figure 1b: Location map of the study area

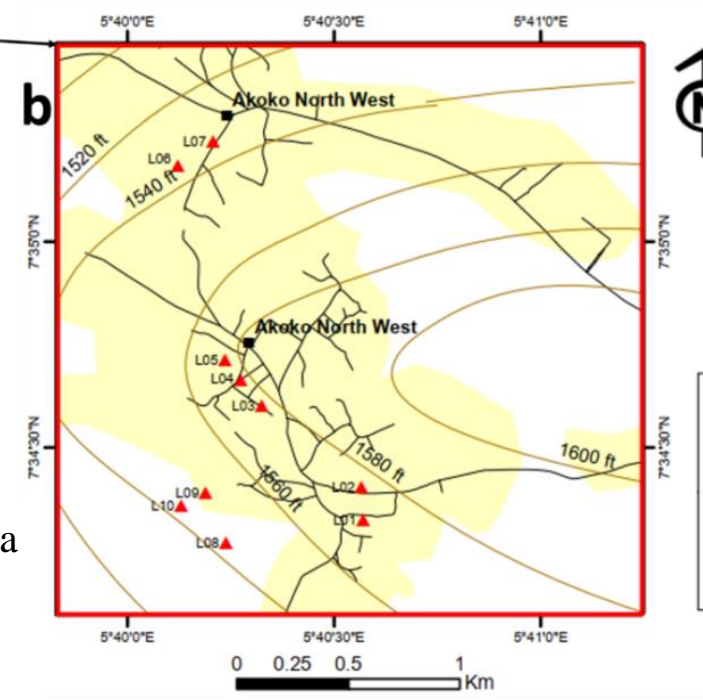

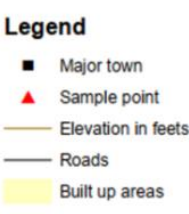




\section{MATERIAL}

\section{Sample collection and laboratory analysis}

Ten groundwater samples were collected from different locations within the study area in pre-washed polyethylene bottles (1.5 litres). The sampling bottles were washed with detergent and rinsed using the groundwater to be sampled. They were transferred to the laboratory for relevant chemical analysis within 24 hours from the time of sample collection. The coordinates for each sampling point was recorded using the global positioning system (GPS) Garmin channel 72 model.

The samples were analysed for major cations $\left(\mathrm{Na}^{+}\right.$, $\left.\mathrm{Ca}^{2+}, \mathrm{Mg}^{2+}, \mathrm{K}^{+}\right)$and anions $\left(\mathrm{Cl}^{-}, \mathrm{SO}_{4}{ }^{2-}, \mathrm{NO}_{3}, \mathrm{PO}_{4}\right)$. The chemical analysis was carried out using the standard methods as suggested by the American Public Health Association (APHA 1998). Sulphate $\left(\mathrm{SO}_{4}{ }^{2-}\right)$ concentration in the groundwater samples was determined using the turbimetric method. The method is based on the principle of formation of barium sulphate in the presence of (acidified $\mathrm{HCl}$ ) barium chloride. The process is enhanced in the presence of glycerol and other organic compound. The absorbance of the colloidal solution was measured against a standard on UV visible Spectrophotometer. Sodium $\left(\mathrm{Na}^{+}\right)$and potassium $\left(\mathrm{K}^{+}\right)$content was determined by flameemission method using a Flame Photometer while calcium $\left(\mathrm{Ca}^{2+}\right)$ and magnesium $\left(\mathrm{Mg}^{2+}\right)$ were determined using Atomic Absorption Spectrometer method. The chloride $\left(\mathrm{Cl}^{-}\right)$concentration was determined using the titration method and the molybdate blue method was used to determine the phosphate content. Spectrophotometric method was used to determine the nitrate concentration. Parameters such as Sodium Absorption Ratio (SAR), Soluble Sodium Percentage (SSP), Magnesium Adsorption Ratio (MAR) and Kelly's Ratio (KR) were calculated using equations (i-iv) to determine the suitability of the water for irrigation.
$\mathrm{SAR}=\mathrm{Na}^{+} / \sqrt{1 / 2}\left(\mathrm{Ca}^{2+}+\mathrm{Mg}^{2+}\right)$

$\mathrm{SSP}=\frac{(N a+K) * 100}{C a+M g+N a+K}$

$\mathrm{KR}=\frac{N a}{C a+M g}$

$\mathrm{MAR}=\frac{M g * 100}{M g+C a}$

Simple summary statistics which includes mean, standard deviation, minimum and maximum values of all the hydro chemical parameters were used to present the data sets. Sampling codes were designated to each of the groundwater samples used in this study and the codes were used in the discussion instead of the actual names of location.

\section{DISCUSSION}

\section{Physical parameters}

The $\mathrm{pH}$ values which is an indication of the acidity and alkalinity of the groundwater ranges from 7.0 to 7.9 with a mean value of 7.41 . The water samples is generally neutral to slightly alkaline and falls within the WHO (2012) permissible limit of $6.5-8.5$ for drinking water. The total dissolved solids (TDS) range from 12.26 to $19.35 \mathrm{mg} / \mathrm{l}$ (Tab. 1). On the basis of Federal Environmental Protection Agency and Federal Ministry of Environment (1991) which specified maximum permissible limit of $1000 \mathrm{mg} / \mathrm{l}$ for TDS, the concentrations of TDS in the present study classify the waters as good for drinking and recreational purposes and fresh (Freeze and Cherry 1979). The classification by Davis and Deweist (1966) shows that the groundwater samples contain low to medium total solids (Tab. 2). The turbidity ranges from 0.01 to 0.05 NTU indicating very low turbidity. This is good because it does not allow microbial contamination which can cause significant damage to humans and animals.

Table 1: Summary of the physical parameter of groundwater samples in parts of Calabar

\begin{tabular}{cllllll}
$\begin{array}{l}\text { Physical } \\
\text { parameter }\end{array}$ & Min & Max & Mean & SD & $\begin{array}{l}\text { WHO } \\
(2012)\end{array}$ & $\begin{array}{l}\% \\
\text { WHO (2012) }\end{array}$ \\
\hline $\begin{array}{c}\mathrm{pH} \\
\text { TDS (mg/L) }\end{array}$ & 7.0 & 7.9 & 7.41 & 0.31 & $6.5-8.5$ & \multicolumn{2}{c}{ Nil } \\
Turbidity (NTU) & 0.01 & 19.35 & 16.42 & 2.48 & 500 & Nil \\
\hline
\end{tabular}

Table 2: Water type and suitability based on TDS

\begin{tabular}{|c|c|c|c|}
\hline Parameter & Classification & Water type/Suitability for irrigation & $\begin{array}{l}\text { No of samples } \\
n=10\end{array}$ \\
\hline $\begin{array}{l}\text { TDS (mg/L) (Freeze } \\
\text { and Cherry, 1979) }\end{array}$ & $\begin{array}{l}<1000 \\
1000-10000 \\
10000-100000 \\
>100000\end{array}$ & $\begin{array}{l}\text { Fresh } \\
\text { Brackish } \\
\text { Saline } \\
\text { Brine }\end{array}$ & $\begin{array}{l}10 \\
\text { Nil } \\
\text { Nil } \\
\text { Nil }\end{array}$ \\
\hline $\begin{array}{l}\text { TDS (mg/L) (Davis } \\
\text { and DeWeist, 1966) }\end{array}$ & $\begin{array}{l}<500 \\
500-1000 \\
1000-3000 \\
>3000\end{array}$ & $\begin{array}{l}\text { Desirable for drinking } \\
\text { Permissible for drinking } \\
\text { Useful for irrigation } \\
\text { Unfit for drinking and irrigation }\end{array}$ & $\begin{array}{l}10 \\
\text { Nil } \\
\text { Nil } \\
\text { Nil }\end{array}$ \\
\hline
\end{tabular}




\section{HYDROCHEMICAL PARAMETERS}

Summary of the measured hydrochemical parameters for the major ions of water from the study area with the World Health Organization standard and the Nigerian Standard for Drinking Water Quality (NSDWQ, 2007) is presented in table 3 . The concentration of calcium, sodium, potassium and magnesium in the water sample range from 10.25 to $19.00 \mathrm{mg} / \mathrm{l}, 12.5 \mathrm{mg} / \mathrm{l}$ to $16.70 \mathrm{mg} / \mathrm{l}$, $11.50 \mathrm{mg} / \mathrm{l}$ to $20.55 \mathrm{mg} / \mathrm{l}$ and $10.60 \mathrm{mg} / \mathrm{l}$ to $16.30 \mathrm{mg} / \mathrm{l}$ respectively. The concentration of sulphate ranged from $11.30 \mathrm{mg} / \mathrm{l}$ to $19.20 \mathrm{mg} / \mathrm{l}$; nitrate concentration ranged from $5.20 \mathrm{mg} / \mathrm{l}$ to $8.40 \mathrm{mg} / \mathrm{l}$ while the concentration of chloride ranges from 86.98 to $351.45 \mathrm{mg} / \mathrm{l}$. Generally, the order of concentration of cations in the groundwater is $\mathrm{K}>\mathrm{Ca}>\mathrm{Na}>\mathrm{Mg}$ while that of the anions is $\mathrm{Cl}>\mathrm{SO}_{4}>\mathrm{NO}_{3}>\mathrm{PO}_{4}$. The concentrations of calcium, magnesium and sodium were within the stipulated groundwater standard by WHO (2012). The concentration of potassium in about $90 \%$ the samples were above the stipulated WHO limits of $12 \mathrm{mg} / \mathrm{l}$. Concentrations of sulphates, nitrates, phosphates and chloride in most locations were within the stipulated standards by WHO and NSDQW. Most of the groundwater samples were found to fall within the stipulated limits implying chemical potability. However, wells 4 and 5 has concentration of chlorides which are above the stipulated standards (WHO and NSDQW).

Table 3: Summary of the chemical parameters of groundwater in parts of Irun Akoko

\begin{tabular}{cllllllll}
$\begin{array}{c}\text { Chemical } \\
\text { parameter }\end{array}$ & Min & Max & Mean & SD & $\begin{array}{l}\text { WHO } \\
(2012)\end{array}$ & NSQDW & $\begin{array}{r}\text { \% } \\
\text { WHO (2012) }\end{array}$ \\
\hline $\begin{array}{c}\mathrm{Ca}^{2+} \\
\mathrm{Mg}^{2+}\end{array}$ & 10.20 & 19.00 & 15.68 & 3.08 & 200 & $\mathrm{NS}$ & Nil & \\
$\mathrm{Na}^{+}$ & 12.50 & 16.30 & 13.52 & 1.84 & 150 & 0.2 & & Nil \\
$\mathrm{K}^{+}$ & 11.50 & 20.55 & 15.14 & 1.96 & 200 & 200 & Nil & \\
$\mathrm{Cl}^{-}$ & 86.98 & 351.50 & 180.31 & 2.88 & 12 & $\mathrm{NS}$ & 90 & \\
$\mathrm{SO}_{4}{ }^{2-}$ & 11.30 & 19.20 & 13.07 & 2.41 & 250 & 250 & 40 & \\
$\mathrm{NO}_{3}{ }^{-}$ & 5.20 & 8.40 & 6.46 & 0.85 & 50 & 50 & Nil \\
$\mathrm{PO}_{4}^{-}$ & 3.50 & 5.46 & 4.30 & 0.69 & $\mathrm{NS}$ & $\mathrm{NS}$ & Nil & \\
\hline
\end{tabular}

\section{${ }^{*}$ All units are in $\mathrm{mg} / \mathrm{L}$}

\section{WATER QUALITY FOR IRRIGATION}

The suitability of groundwater for irrigation purposes is dependent upon the mineral constituent of the water on both plants and soil (Todd, 1980). The SAR in water sample ranged from 0.52 to 0.81 and are classified as excellent for irrigation purposes (Tables 4 and 5). Water with $\mathrm{SAR}<3$ is safe for irrigating ornamental landscape plant while those with $S A R>9$ can lead to severe permeability problems in fine textured soils (Harivandi 1991). The values of SSP $<50$ indicate good quality of water and higher values $(>50)$ show the water is unsafe for irrigation. The water samples have SSP values less than 50, hence suitable for irrigation. According to
Stallard and Edmond (1983), the water samples fall within fair to good for the purpose of irrigation. Kelly Ratio of one or less than 1 is an indication of good quality water for irrigation, whereas above 1 is suggestive of unsuitability for agricultural purpose due to alkali hazards. Based on the KR values, the water samples are good for irrigation regarding alkali hazard. Magnesium ratio of more than $50 \%$ in a water body can make the water poisonous to plants. The values obtained for MAR within the study area ranged from $55.00 \%$ to $68.90 \%$. None of the water samples fall within $50 \%$ that is considered suitable with no hazardous effects to the soil (Schoeller, 1965).

Table 4: summary of water irrigation criteria

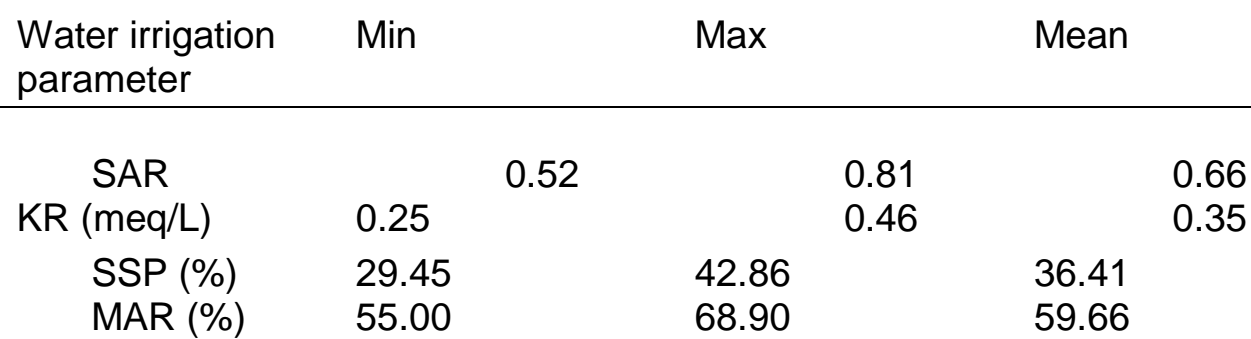


Table 5: Some parameter indices for rating the sustainability of groundwater quality for irrigation

(Ayers and Westcot 1985; Wilcox 1948)

\begin{tabular}{clllc} 
Class & TDS $(\mathrm{mg} / \mathrm{L})$ & SAR & SSP & $\begin{array}{c}\text { Suitability for } \\
\text { irrigation }\end{array}$ \\
\hline I & $<117.51$ & $<10$ & $<20$ & Excellent \\
II & $117.51-508.61$ & $10-18$ & $20-40$ & Good \\
III & $>508.61$ & $18-26$ & $40-80$ & Fair \\
IV & ------ & $>26$ & $>80$ & Poor \\
\hline
\end{tabular}

\section{CONCLUSIONS}

Ten samples from hand dug wells were collected within Irun Akoko, southwestern Nigeria. The purpose was to determine the quality for both drinking and irrigation purposes. The $\mathrm{pH}$ and TDS of the groundwater revealed that the water varied within neutral to slightly alkaline and fresh respectively. $\mathrm{Ca}, \mathrm{Mg}, \mathrm{Na}, \mathrm{SO}_{4}, \mathrm{PO}_{4}$ and $\mathrm{NO}_{3}$ were all within recommended standard for drinking purposes. The concentration of potassium in about $90 \%$ and chloride in about $40 \%$ of the water samples were above the World Health Organization (WHO) standard for drinking water. SAR in water sample ranged from 0.52 to 0.81 and are classified as excellent for irrigation. The Soluble Sodium Percentage (SSP) values classified eighty percent of the water to be of good quality and the remaining samples as fair for irrigation purposes. Kelly's ratio values ranged between 0.25 and $0.46 \mathrm{meq} / \mathrm{L}$. The values obtained were lower than the permissible limit of 1.0 for all the samples.

\section{REFERENCES}

Alrumman S. A., El-kott A. F. and Kehsk M. A., 2016. Water pollution: Source and treatment. American journal of Environmental Engineering, 6(3):88-98.

APHA, 1998. Standard methods for the examination of water and wastewater, 19th edition, American Public Health Association, Washington DC, USASS.

Ayers R. S. and Westcot D. W., 1985. Water quality for agriculture FAO irrigation and drain. 29(1):1109

Davis S. N. and DeWiest R.J.M., 1966. Hydrogeology. Wiley, New York

Federal Environment Protection Agency/Federal Ministry of Environment (FEPA/FMENV) 1991. National guidelines and standards for industrial effluents, gaseous emissions and hazardous waste management in Nigeria. Government Notice.

Freeze R. A. and Cherry J. A., 1979. Groundwater. Prentice Hall, Englewood Cliffs

Harivandi M. A., 1999. Interpreting tuffgrass irrigation water test results. Publication 8009. Regents of the University of California. Division of Agriculture and Natural Resources
Haseena M, Malik M. F., 2017. Water pollution and human health. Environ Risk Assess Remediat., 1(3):16-19

NSDWQ, 2007, "Nigerian Standard for Drinking Water Quality", Nigerian Industrial Standard, NIS:554, 1-14

Ondo State Ministry of Agriculture (2005). Climatic Data; Department of Agro-Meteorology: Akure, Nigeria.

Odukoya A. M., 2015. Geochemical and quality assessment of groundwater in some Nigerian basement complex. Int. J. Environ. Sci. Technol. 12:3643-3656 DOI 10.1007/s13762-015-0789-y

Olatunji J. A., Odediran, O. A., Obaro, R. I. and Olasehinde P. I., 2015. Assessment of Groundwater Quality of Ilorin Metropolis using Water Quality Index Approach. NIGERIAN JOURNAL OF TECHNOLOGICAL DEVELOPMENT, VOL. 12, NO. 1,

Olorunfemi M. O. and Fasuyi S. A., 1993. Aquifer types and the Geologic/Hydro geologic characteristics of part of the central basement terrain, Niger state. J. Afr. Earth Sci., Vol. 16, pp. 309-317

Pawari M. J., Gawande S., 2015. Groundwater pollution and its consequence. International journal of engineering research and general science, 3(4):773-76

Richards L. A., 1954. Diagnosis and improvement of saline and alkali soil. Agricultural Handbook 60. USDA, Washington

Schoeller H., 1965. Qualitative evaluation of groundwater resources. In: Methods and techniques of groundwater investigations and development an international guide for research and practice. UNESCO, pp 54-83 UNESCO 2007 UNESCO water portal newsletter no 161: water related disease.

Stallard R. F. and Edmond J. M., 1983. Geochemistry of the Amazon, the influence of geology and weathering environment on the dissolved load. J Geophys Res 88:9671-9688. Doi:10.1029/ JC088iC14p09671. 
Soladoye O. and Ajibade L. T., 2014. A Groundwater Quality Study of Lagos State. Nigeria International Journal of Applied Science and Technology, vol. 4, No. 4, pp. 271-281

Todd D. K., 1980. Groundwater hydrology, 2nd edn. Willey, New York
Wilcox L. V., 1948. The quality of water for irrigation use. US Department of Agriculture Technology Washington DC Bulletin 962, 40 pp

WHO 2012. Guidelines for drinking water quality, recommendations, 4th edn. World Health Organization library cataloguing in publication data. http://www.int

Appendix I: chemical parameters of water samples in parts of Irun-Akoko

$\begin{array}{lllllllll}\begin{array}{l}\text { Water } \\ \text { source }\end{array} & \begin{array}{l}\mathrm{Ca} \\ (\mathrm{mg} / \mathrm{l})\end{array} & \begin{array}{l}\mathrm{Mg} \\ (\mathrm{mg} / \mathrm{l})\end{array} & \begin{array}{l}\mathrm{Na} \\ (\mathrm{mg} / \mathrm{l})\end{array} & \begin{array}{l}\mathrm{K} \\ (\mathrm{mg} / \mathrm{l})\end{array} & \begin{array}{l}\mathrm{Cl} \\ (\mathrm{mg} / \mathrm{l})\end{array} & \begin{array}{l}\mathrm{NO}_{3} \\ (\mathrm{mg} / \mathrm{l})\end{array} & \begin{array}{l}\mathrm{PO}_{4} \\ (\mathrm{mg} / \mathrm{l})\end{array} & \begin{array}{l}\mathrm{SO}_{4} \\ (\mathrm{mg} / \mathrm{l})\end{array} \\ \text { WL1 } & 12.5 & 11.40 & 13.50 & 15.30 & 86.98 & 6.20 & 3.75 & 11.35 \\ \text { WL2 } & 14.3 & 10.60 & 16.70 & 18.50 & 92.30 & 6.20 & 3.65 & 11.31 \\ \text { WL3 } & 10.2 & 13.60 & 14.30 & 11.50 & 275.10 & 6.23 & 3.50 & 11.40 \\ \text { WL4 } & 16.2 & 14.30 & 13.50 & 19.50 & 351.50 & 6.22 & 4.50 & 11.30 \\ \text { WL5 } & 17.1 & 13.00 & 18.50 & 20.55 & 264.50 & 6.20 & 3.50 & 12.50 \\ \text { WL6 } & 18.2 & 14.50 & 16.50 & 18.20 & 97.63 & 5.20 & 5.40 & 13.50 \\ \text { WJ7 } & 18.5 & 11.60 & 15.80 & 19.60 & 168.60 & 6.10 & 4.70 & 12.80 \\ \text { WL8 } & 12.6 & 14.70 & 16.70 & 14.80 & 86.98 & 8.40 & 5.20 & 19.20 \\ \text { WL9 } & 18.2 & 15.20 & 12.50 & 14.50 & 216.50 & 7.30 & 4.30 & 12.80 \\ \text { WL10 } & 19.0 & 16.30 & 13.40 & 15.80 & 163.00 & 6.50 & 4.50 & 14.50\end{array}$

Appendix II: Irrigation parameters of water samples in parts of Irun Akoko

\begin{tabular}{|l|l|l|l|l|}
\hline Water source & SAR & $\begin{array}{l}\text { MAR } \\
(\%)\end{array}$ & $\begin{array}{l}\text { SSP } \\
(\%)\end{array}$ & $\begin{array}{l}\text { KR } \\
(\mathrm{meq} / \mathrm{L})\end{array}$ \\
\hline WL1 & 0.67 & 60.13 & 38.28 & 0.37 \\
\hline WL2 & 0.58 & 55.00 & 42.86 & 0.46 \\
\hline WL3 & 0.69 & 68.90 & 35.69 & 0.38 \\
\hline WL4 & 0.59 & 59.50 & 35.28 & 0.30 \\
\hline WL5 & 0.81 & 55.67 & 40.67 & 0.41 \\
\hline WL6 & 0.70 & 57.08 & 35.95 & 0.34 \\
\hline WJ7 & 0.71 & 57.05 & 38.51 & 0.36 \\
\hline WL8 & 0.76 & 66.13 & 37.37 & 0.39 \\
\hline WL9 & 0.52 & 58.26 & 29.45 & 0.25 \\
\hline WL10 & 0.54 & 58.87 & 30.00 & 0.25 \\
\hline
\end{tabular}

Appendix III: Physical parameters of water samples in parts of Irun Akoko

\begin{tabular}{|l|l|l|l|l|l|l|}
\hline $\begin{array}{l}\text { Water } \\
\text { source }\end{array}$ & $\mathrm{pH}$ & $\begin{array}{l}\text { TH } \\
(\mathrm{mg} / \mathrm{l})\end{array}$ & $\begin{array}{l}\text { TDS } \\
(\mathrm{mg} / \mathrm{l})\end{array}$ & $\begin{array}{l}\text { TSS } \\
(\mathrm{mg} / \mathrm{l})\end{array}$ & $\begin{array}{l}\text { TS } \\
(\mathrm{mg} / \mathrm{l})\end{array}$ & $\begin{array}{l}\text { Turbidity } \\
(\mathrm{NTU})\end{array}$ \\
\hline WL1 & 7.9 & 127.0 & 13.35 & 26.91 & 40.26 & 0.03 \\
\hline WL2 & 7.0 & 121.0 & 12.26 & 25.52 & 37.78 & 0.02 \\
\hline WL3 & 7.3 & 124.0 & 16.55 & 34.81 & 51.36 & 0.01 \\
\hline WL4 & 7.0 & 123.0 & 19.21 & 24.19 & 43.40 & 0.05 \\
\hline WL5 & 7.5 & 124.0 & 18.26 & 23.27 & 41.53 & 0.04 \\
\hline WL6 & 7.4 & 175.0 & 18.50 & 27.15 & 45.65 & 0.03 \\
\hline WL7 & 7.3 & 120.0 & 15.75 & 31.80 & 47.55 & 0.04 \\
\hline WL8 & 7.9 & 121.8 & 14.50 & 31.90 & 46.40 & 0.02 \\
\hline WL9 & 7.3 & 120.2 & 16.50 & 27.00 & 43.50 & 0.03 \\
\hline WL10 & 7.5 & 180.0 & 19.35 & 28.15 & 47.50 & 0.02 \\
\hline
\end{tabular}


Appendix IV: Coordinates of the sample points

$\begin{array}{llll}\text { Location } & \text { Elevation }(\mathrm{m}) & \text { Latitude } & \text { Longitude } \\ 1 & 491.03 & \mathrm{~N} 07^{0} 34.327 & \mathrm{E} 005^{0} 40.570 \\ 2 & 501.40 & \mathrm{~N} 07^{0} 34.405 & \mathrm{E} 005^{0} 40.567 \\ 3 & 517.86 & \mathrm{~N} 07^{0} 34.604 & \mathrm{E} 005^{0} 40.325 \\ 4 & 519.38 & \mathrm{~N} 07^{0} 34.666 & \mathrm{E} 005^{0} 40.275 \\ 5 & 514.80 & \mathrm{~N} 07^{0} 34.713 & \mathrm{E} 005^{4} 40.236 \\ 6 & 462.08 & \mathrm{~N} 07^{0} 35.184 & \mathrm{E} 005^{0} 40.122 \\ 7 & 461.77 & \mathrm{~N} 07^{0} 35.241 & \mathrm{E} 005^{0} 40.207 \\ 8 & 462.38 & \mathrm{~N} 07^{0} 34.269 & \mathrm{E} 005^{0} 40.239 \\ 9 & 459.94 & \mathrm{~N} 07^{0} 34.392 & \mathrm{E} 005^{0} 40.190 \\ 10 & 458.42 & \mathrm{~N} 07^{0} 34.360 & \mathrm{E} 005^{0} 40.130\end{array}$

